\title{
Author Correction: Teachers' narrative of learning to program in a professional development effort and the relation to the rhetoric of computational thinking
}

\author{
Natalia Monjelat ${ }^{1}$ (D) Annika Lantz-Andersson ${ }^{2}$ (D) \\ Published online: 8 January 2020 \\ (C) Springer Science+Business Media, LLC, part of Springer Nature 2020
}

\section{Author Correction: Education and Information Technologies https://doi.org/10.1007/s10639-019-10048-8}

Acknowledgements was not included in the original article and is now provided to this article.

Acknowledgements We wish to thank our colleagues Patrik Lilja, Catarina Player-Koro, AnnaLena Godhe, and Thomas Hillman at the University of Gothenburg for their contributions on the debate concerning computational thinking and their Blog-post, published in 2016, https://it.blogg. gu.se/2016/04/28/programmering2/, of which the discussion in this study draws. This research is a part of a larger research project named "Aprender a Programar en Primaria: Hacia la construcción de tecnologias para la inclusión social" (PICT 2016-1530) funded by the Argentinian Agencia Nacional de promoción científica y tecnológica (ANPCyT-FonCyT).

Publisher's note Springer Nature remains neutral with regard to jurisdictional claims in published maps and institutional affiliations.

The online version of the original article can be found at https://doi.org/10.1007/s10639-019-10048-8

Natalia Monjelat

monjelat@irice-conicet.gov.ar

Annika Lantz-Andersson

annika.lantz-andersson@ped.gu.se

1 Instituto Rosario de Investigaciones en Ciencias de la Educación (IRICE), National Scientific and Technical Research Council (CONICET), 27 de Febrero 210 Bis, Rosario, Santa Fe, Argentina

2 Department of Education, Communication and Learning, University of Gothenburg, SE-405 30 Gothenburg, Sweden 